Creative Commons User License: CC BY-NC-ND

Abstracted by: EBSCOhost, Electronic Journals Service (EJS),

Google Scholar, Journal Seek, Scientific Commons,

Food and Agricultural Organization (FAO), CABI and Scopus
Journal of Agricultural Extension

Vol. 25 (2) April, 2021

ISSN(e): 24086851; ISSN(Print); 1119944X

http://journal.aesonnigeria.org

http://www.ajol.info/index.php/jae

Email: editorinchief@aesonnigeria.org

\title{
Capacity Building Needs of Small-Holder Cocoyam (Xanthosoma Sagittifoliuu) Farmers in Selected Rural Communities of Akwa Ibom State, Nigeria
}

https://dx.doi.org/10.4314/jae.v25i2.3

\section{Nkeme, Kesit Kufre,}

Department of Agricultural Economics and Extension, Faculty of Agriculture,

Akwa Ibom State University, Ikot Akpaden, Mkpat Enin, P.M.B. 1167, Uyo, Akwa Ibom State, Nigeria. Nkemekesit6@gmail.com; +2348028316420.

\section{Ekanem, Jemimah Timothy}

Department of Agricultural Economics and Extension, Faculty of Agriculture,

Akwa Ibom State University, Ikot Akpaden, Mkpat Enin, P.M.B. 1167, Uyo, Akwa Ibom State, Nigeria. jemimahekanem@aksu.edu.ng; +2348060790069.

\section{Nse, Victoria Asuquo}

Department of Agricultural Economics and Extension, Faculty of Agriculture,

Akwa Ibom State University, Ikot Akpaden, Mkpat Enin, P.M.B. 1167, Uyo, Akwa Ibom State, Nigeria.Vickkynse7@gmail,com; +2348030706640

\section{Abstract:}

The study investigated the capacity building needs of small-holder cocoyam farmers in Akwa Ibom State, Nigeria during the 2018 cropping season. Data were randomly collected from 130 respondents selected through a multi-stage sampling procedure using questionnaire and analysed using descriptive statistics, net returns model and budgeting technique. For agronomic management practice, result showed that the major sources of land acquisition and labour were inheritance (63\%) and hired labour (52.6\%). The majority (71.6\%) of sampled farmers cultivated between 20 and 80 stands of cocoyam per farm. Result further showed that the major marketing channels of cocoyam were; farm gate (40.7\%) and rural markets $(24.7 \%$. The main sources of information for cocoyam farmers were family and friends (40.9\%), radio and television (18\%) and extension agents (10.5\%). The cost-returns analysis showed a gross margin and net return of N1, 164,500.00, and N494, 700.00, respectively, and the return per capital of N1.74. The most capacity building needs of cocoyam farmers were information on processing technology $(\bar{x}=3.31)$, farm credit information $(\bar{x}=3.19)$, information on pest/ disease control $(\bar{x}=3.17)$, storage information $(\bar{x}=3.15)$, record keeping/ evaluation need ( $\bar{x}=2.92)$ and effective cocoyam marketing $(\bar{x}=2.88)$. The major constraints militating against cocoyam production in the study area were; absence of marketing information ( $\bar{x}=2.57)$, poor record keeping $(\bar{x}=2.57)$, labour scarcity $(\bar{x}=2.42)$, pest and disease $(\bar{x}=2.34)$, lack of improved variety of planting material $(\bar{x}=2.30)$. Provision of marketing channels information to farmers, enhancing access to extension contact and periodic training of farmers ' on improved management practices are avenues to boost cocoyam production.

Keywords: Capacity building needs, small holders cocoyam farmer 
Creative Commons User License: CC BY-NC-ND

Abstracted by: EBSCOhost, Electronic Journals Service (EJS),

Google Scholar, Journal Seek, Scientific Commons,

Food and Agricultural Organization (FAO), CABI and Scopus
Journal of Agricultural Extension

Vol. 25 (2) April, 2021

ISSN(e): 24086851; ISSN(Print); 1119944X

http://journal.aesonnigeria.org

http://www.ajol.info/index.php/jae

Email: editorinchief@aesonnigeria.org

\section{Introduction}

Nutritional deficiencies have continued to be a major health challenge faced by the rural resource poor in Nigeria (Ayogu, Afiaenyi, Madukwe \& Udenta, 2018). Moreover, the agricultural production sector has been stagnated, food production increased at the rate of $2.5 \%$ while food demand increased at more than $3.5 \%$, contributing an average of $23.5 \%$ to gross domestic product and generating only $5.1 \%$ of export earnings in the last five years (Akpabio, 2018). Thus, the sector has not been able to keep pace with the country's rapid population growth rate. Cocoyam is one of the most important food crops in tropical and sub-tropical Africa because it stores more and better than other tuber and root crops, reputed for its capacity to tolerate marginal environment and as a good inexpensive source of energy in the diets. It is widely consumed by the rural resource poor as it is regarded as a rich source vitamin, containing a good level of pro-vitamin A carotenoids, but during the past few years, cocoyam production output in Nigeria has declined persistently as reported by Bassey, Umoh, Ndaeyo, Nneke \& Akpan(2016). Omotesho, Kayode, Adebayo, Akinrinde \& Mohammed (2020) reported that the production and productivity of cocoyam in Nigeria is dwindling in recent year with yield less than 18 metric tonnes per hectare. This is why Enibe, Nwobodo, Nworgi \& Okonkwo (2019), defined cocoyam as a neglected food crop, which has become an endangered crop on the verge of extinction. They generally believe that most families no longer consume it because it is not readily available for consumption even during its season, as a result of reduction in its production level. Hence, cocoyam has almost disappeared despite its socio-economic relevance, thus triggering food insecurity and threat to livelihood among the predominantly farming populace.

Since cocoyam introduction in 100.A.D according to the Federal Office of Statistics (FOS, 2017), it has become a traditional staple crop which is mostly intercropped in a previously established farm by subsistence farmers having $0.5-2.0$ hectares in the rural areas of South-South, South-West and Southeast regions of Nigeria (Anyanwu, 2019). In Nigeria, the importance of cocoyam is indispensable, based on the major role it plays in livelihood among the rural dwellers because it serves as an important source of human nutrition, income generation, employment as well as dietary calories especially in times of shortage and economic stress. Despite this, Nigeria is the world's largest producer of cocoyam with an annual production of 5.49 million metric tonnes, equivalent to $45.9 \%$ of the world's production and $72.2 \%$ total output of cocoyam in West Africa (Bassey et al., 2016).

In human diet, cocoyam has superior nutritional value over other major root and tuber crops like yam and cassava, having higher protein contents, essential amino acid, dietary fibre, sulphur, antioxidants in addition to moderate proportions of minerals and vitamins. Together with slow digesting complex carbohydrates, moderate amounts of fibre in the food help check gradual rise in blood sugar levels (Umoh, 2016). According to Food and Agriculture Organization (FAO, 2017), in photo-medicine, daily consumption of cocoyam with palm oil for 3 months is recommended for diabetic patients and prevention of prostrate and breast cancers. Cocoyam consists of tender leaves that are nutritious spinach-like vegetable which 
Creative Commons User License: CC BY-NC-ND

Abstracted by: EBSCOhost, Electronic Journals Service (EJS), Google Scholar, Journal Seek, Scientific Commons,

Food and Agricultural Organization (FAO), CABI and Scopus
Journal of Agricultural Extension

Vol. 25 (2) April, 2021

ISSN(e): 24086851; ISSN(Print); 1119944X

http://journal.aesonnigeria.org

http://www.ajol.info/index.php/jae

Email: editorinchief@aesonnigeria.org

gives a lot of minerals, vitamins (A and C), and thiamine (Umoh, 2016), which is an advantage in modern diets where a lot of refined carbohydrate is consumed. The flowers also are used as spice to garnish and flavour food. The economic potential of cocoyam is high, not only as a food material (meals, supplement in soup thickening and snack) but also in the confectionery and livestock businesses and as agroindustrial raw material for pharmaceutical industries (Chukwu, 2016).

With the immense nutritional and medicinal potentials of cocoyam as revealed by several studies and programmes on food crop production embarked upon by the Federal Government of Nigeria, it still ranks third in importance, total output and extent of production after yam and cassava among staple root and tuber crops (Umoh, 2016). Even though cocoyam is one of the major five tuber crops produced in Nigeria for local consumption, it is common knowledge that cocoyam is classified among the underutilized crops and the future directions for its production and marketing remain uncertain, hence, has become an endangered food crop. Consequently, the decline in production which affects the general acceptability and marketing of the crop could be attributable to the lack of information on its nutritional, functional properties, poor preservation techniques and diversities of the food forms to a large percentage of the populace (Okudu, Okwu and Umoh, 2018). Umoh, (2016) have also pinned the decline on cocoyam utilization to limited information on cultivation, low financial returns and the notion that it is a poor man`s crop.

Inadequate dissemination of technological information on availability of marketing channel, availability of facilities for storage, availability of improved planting materials, transport and pest and disease resistant varieties has resulted in low farm income, weak financial position, and poor funding of small-holder farmers economic activities. Consequently, cocoyam cultivation continues to be characterised by the use of indigenous planting materials with high labour-intensive production. In this regard cocoyam farmers are shifting from cocoyam cultivation to other more competitive root and tuber crops. The commercial production level of cocoyam is perceived to be low; it is observed not to be commonly found in most markets like other root and tuber crops such as cassava and yam; its scarcity makes it expensive where it is available. Farmers' use of resources and information technologies efficiently are of importance in stem/tuber crop production (Umoh, 2016). There has been growing concern about the capability of cocoyam farmers to have an effective and efficient means of meeting the increasing demand for cocoyam; the farmer has to produce more in order to increase food production and provide food security for the fast-growing population of rural areas (Anyanwu, 2019). Cocoyam is currently receiving a rebirth as research discoveries have shown that cocoyam is becoming a 'crop with promising economic value'. Therefore, meeting the huge supply deficit has become necessary and more research attention needs to be given to cocoyam production. It is against this backdrop that the study investigated the capacity building needs of cocoyam farmers for improving sustainable livelihood in rural communities of Akwa Ibom State, Nigeria. 
Creative Commons User License: CC BY-NC-ND

Abstracted by: EBSCOhost, Electronic Journals Service (EJS), Google Scholar, Journal Seek, Scientific Commons,

Food and Agricultural Organization (FAO), CABI and Scopus
Journal of Agricultural Extension

Vol. 25 (2) April, 2021

ISSN(e): 24086851; ISSN(Print); 1119944X

http://journal.aesonnigeria.org

http://www.ajol.info/index.php/jae

Email: editorinchief@aesonnigeria.org

\section{Objectives:}

The specific objectives of this study include:

examine the sources of information on cocoyam by the respondents

examine of the agronomic management practices used

identify the marketing channels used in cocoyam

identify the capacity building needs of cocoyam farmers

identify constraints to cocoyam production

\section{Methodology}

The study was conducted in Akwa lbom State in the Southeast ecological zone of Nigeria. It is located at latitude 4032 ' $\mathrm{N}$ and $5033^{\prime} \mathrm{N}$ of the equator and Longitude 70 $25^{\prime} \mathrm{E}$ and $5025^{\prime} \mathrm{E}$ of the Greenwich meridian. The State has a total population of 7,245, 935,746 (National Population Commission NPC, 2006) with estimated total area put at $7,081 \mathrm{~km}^{2}(2,734 \mathrm{Sq} \mathrm{m})$. Moreover, 73 percent of the population live in the rural areas and farming is the major occupation of the people who normally grow major crops such as cassava, maize, cocoyam, oil palm, coconut, plantain, banana, fluted pumpkin, waterleaves and rearing of livestock like poultry, goat, sheep, cattle, grass cutter, rabbit and fishing mostly practised by those in the riverine areas. The population of the study was all cocoyam farmers in the agricultural zones of the state.

Akwa Ibom State is made up of six agricultural zones which include Uyo, Eket, Oron, Ikot Ekpene, Etinan and Abak. A multistage sampling technique was used in selecting respondents for this study. The first stage was the purposive selection of five (5) Agricultural zones namely: Uyo, Abak, Etinan, Eket and Oron due to predominance of cocoyam activities in the zones. In second stage, one block was purposively selected based on their intensity in cocoyam production from the selected zones making five blocks, thirdly, two circles were purposively selected from the five blocks giving ten circles based on the abundance of cocoyam production. Finally, thirteen (13) farmers were randomly selected from each of the selected circles giving a total sample size of one hundred and thirty (130) farmers. Primary data were collected through well-structured questionnaire, which were administered to the respondents.

Data were analysed using means, standard deviation and net income model.

The net returns model was used to estimate the costs and returns of cocoyam production. The formula for net returns model is stated as follows.

$\mathrm{NR}=\mathrm{TR}-\mathrm{TC}$

$T C=T F C+T V C$

$\mathrm{GM}=\mathrm{TR}-\mathrm{TVC}$

Where;

NR = Net Return (\#);

TR = Total Revenue (\#);

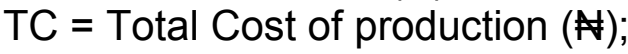

TVC = Total Variable Cost (\#); 
TFC = Total Fixed Cost ( $\$$;

$\mathrm{GM}=$ Gross Margin (\#).

Returns per capital invested (RCl) was obtained by dividing the gross margin (GM) by the total cost (TC). Decision Rule of returns per capital invested (RCI): RNI $>1$, it implies the enterprise is profitable; $\mathrm{RNI}=1$, it implies that the farmer is operating at breakeven point and $\mathrm{RNI}<1$, the farmer is at a loss.

\section{Results and Discussion}

\section{Respondents`Sources of Information on Cocoyam}

Table 1 shows that most $(40.9 \%)$ of the respondents sourced their cocoyam production and marketing information from friends and relatives. This agrees with the findings of Nkeme, Udo and Udousung (2017) that in the rural areas friends, relatives and other farmers aid in disseminating agricultural production information.

\section{Table 1: Sources of information on cocoyam}

\section{Source of information}

Friends \& relatives

Radio and Television

Exhibition

Workshop

Training programme

Newspaper

Other farmers

Extension

\section{Percentage(161*)}

40.9

18.0

10.5

Source: Field data, 2019

${ }^{*}$ Multiple responses

\section{Types of Agronomic Management Practices in Cocoyam Production}

Table 2 reveals different types of agronomic management practices employed by cocoyam farmers in the study area. Result shows that most (63\%) of the respondents acquired land for cocoyam cultivation through inheritance. The major source of labour for their cocoyam enterprise was hired labour (52.6\%); the high use of hired labour by cocoyam farmers reflects the low household size in the study area, which compelled them to embrace hired labour, which impacted severely on cocoyam production cost in the study area. For the number of tubers stand per farm, 
Creative Commons User License: CC BY-NC-ND

Abstracted by: EBSCOhost, Electronic Journals Service (EJS), Google Scholar, Journal Seek, Scientific Commons,

Food and Agricultural Organization (FAO), CABI and Scopus

http://eoi.citefactor.org/10.11226/v25i2
Journal of Agricultural Extension

Vol. 25 (2) April, 2021

ISSN(e): 24086851; ISSN(Print); 1119944X

http://journal.aesonnigeria.org

http://www.ajol.info/index.php/jae

Email: editorinchief@aesonnigeria.org

majority (71.6\%) of sampled respondents had between $20-80$ stands of cocoyam per farm. This suggests that cocoyam production in the study area is dominated by small scale farmers. Furthermore, result reveals that majority (73.8\%) of farmers harvest their cocoyam when it is mature and at the peak of harvesting season.

Table 2: Agronomic management practices

\begin{tabular}{lc}
\hline Agronomic Management & Percentage (130) \\
Practices & \\
\hline Land acquisition & 63.8 \\
Inheritance & 8.5 \\
Purchase & 27.7 \\
Lease & 0.0 \\
Co-operative & \\
Source of Labour & 39.4 \\
Family & 52.6 \\
Hired & 7.0 \\
Both & \\
Root/Tuber Density & 12.3 \\
20-40 stands & 3.1 \\
41-60 stands & 56.2 \\
61-80 stands & 21.5 \\
81-100 stands & 6.9 \\
>100 stands & \\
Frequency of Harvest & 73.8 \\
Once a year & 26.2 \\
Twice a year & \\
\hline
\end{tabular}

Source: Field survey data, 2019

\section{Marketing Channel of Cocoyam Farmers}

Table 3 presents the marketing channel used by cocoyam farmers. A greater part of cocoyam farmers $(40.7 \%)$ sold their products at the farm gate. This finding implies that about $84.5 \%$ of the total cocoyam produced in the study area is marketed and consumed within the vicinity. This finding is in agreement with Nwafor (2018), who found that $89 \%$ of the respondents use the farm gate as their major marketing channel. This is an evidence of subsistence nature and low scale production by rural farmers as asserted by Udoh, and Akpan, (2015). It further indicates that smallholder farmers prefer market channels where they do not have to incur additional transport costs or additional risk of exposure to hazards by travelling long distances to market their produce. It also suggests that farmers prefer to receive immediate payments for produce, while also taking as important their personal relationships with buyers. On the other hand, it accounts for the low prices of products received by farmers as 
Creative Commons User License: CC BY-NC-ND

Abstracted by: EBSCOhost, Electronic Journals Service (EJS), Google Scholar, Journal Seek, Scientific Commons,

Food and Agricultural Organization (FAO), CABI and Scopus

http://eoi.citefactor.org/10.11226/v25i2
Journal of Agricultural Extension

Vol. 25 (2) April, 2021

ISSN(e): 24086851; ISSN(Print); 1119944X

http://journal.aesonnigeria.org

http://www.ajol.info/index.php/jae

Email: editorinchief@aesonnigeria.org

corroborated by Opata (2018) which weakens the farmers' morale and may lead to reduced or complete stoppage of production.

Table 3: Marketing channel used

\begin{tabular}{lc}
\hline Channel & Percentage $\left(\mathbf{1 6 2}^{\star}\right)$ \\
\hline Farm gate & 40.7 \\
Distant market & 10.5 \\
Nearby town & 5.0 \\
Road side & 19.1 \\
Rural market & 24.7 \\
\hline
\end{tabular}

\section{Cost-return of Cocoyam Production}

Table 4 shows the total variable cost (total cost items) of N635, 500.00 per production period while the fixed cost was N34, 300.00. The gross margin and net return of production were N1, 164,500.00 and N494, 700.00, respectively. The return per capital estimated was $\mathrm{N} 1.74$, implying that for every $\mathrm{N} 1$ invested in cocoyam production, $\mathrm{N} 1.74$ was the revenue. The rate of return on capital invested $(\mathrm{RORCI})$ estimate was 0.74 . This implies that every $\mathrm{N} 1$ invested gives a profit of 74 kobo from cocoyam production. The findings concluded that cocoyam production in the study area is a crop with promising economic value. This is in agreement with Enibe et al., (2019) whose findings revealed that, cocoyam business is profitable because for every one naira invested, the wholesalers and retailers made 32 kobo and 62 kobo respectively.

\section{Table 4: Net return of cocoyam per production}

Variables

Revenue (Total Value of Production (TVP)

Cost items

Land clearing/Preparation

Planting materials

Labour for Cultivation

Cost of manure

Application of manure

Weeding (twice)

Harvesting

Transport

Total variable cost

Gross Margin

Fixed Cost (FC)

Rent on land

Depreciation of tools

Total Fixed Cost

Total Cost

Net Farm Income (NFI)

Return per capital invested

Average Value/ha

5tonnes at N300

40mandays/N1500

$1000 \mathrm{~kg}$ at N500/kg

10 mandays at $\mathrm{N} 1300$

$500 \mathrm{~kg}$ at $\mathrm{N} 500 / 50 \mathrm{~kg}$

7 mandays at $\mathrm{N} 500$

30 mandays at $\mathrm{N} 1500$

10 mandays at $\mathrm{N} 400$
Total Value Naira ( N) ha

$1,500.000$

$60,000.00$

$500,000.00$

$13,000.00$

$5,000.00$

$3,500.00$

$45,000.00$

4000.00

$\mathrm{N} 5000.00$

635500.00

$1,164,500.00$

$30,000.00$

$4,300.00$

$34,300.00$

$669,800.00$

$494,700.00$ 
Creative Commons User License: CC BY-NC-ND

Abstracted by: EBSCOhost, Electronic Journals Service (EJS),

Google Scholar, Journal Seek, Scientific Commons,

Food and Agricultural Organization (FAO), CABI and Scopus
Journal of Agricultural Extension

Vol. 25 (2) April, 2021

ISSN(e): 24086851; ISSN(Print); 1119944X

http://journal.aesonnigeria.org

http://www.ajol.info/index.php/jae

Email: editorinchief@aesonnigeria.org

Sources: Field survey, 2019. Decision rule: $\mathrm{RCl}=1$ shows that the farmer is operating at breakeven point. $\mathrm{RCl}>1.00$ shows that the production is profitable

\section{Capacity Building Needs of Cocoyam Farmers}

Table 5 presents the mean distribution of cocoyam farmers on their responses on their capacity building needs. Result of the analysis showed that information on cocoyam processing technology was mostly needed with a mean value of 3.31 , followed by farm credit related information $(\bar{x}=3.19)$, pest and disease control $(\bar{x}=3.17)$, information on effective storage of cocoyam $(\bar{x}=3.15)$, record keeping and evaluation $(\bar{x}=2.92)$, information on cocoyam marketing $(\bar{x}=2.88)$ as well as information on health benefit of cocoyam $(\bar{x}=2.84)$.

The high need of information pertaining to cocoyam processing is borne out of its perishable nature. Information on pest and disease control is necessary in order to minimize the rate of pest infestation while record keeping will enable farmers keep track of their production activities and examine their returns. In addition, marketing information is desirable for appropriate marketing of harvested cocoyam. This is the case because cocoyam is highly perishable and should be marketed as soon as possible in the face of insufficient storage facilities.

The high-capacity building need for cocoyam processing technology, farm credit related information, effective storage, record keeping/evaluation, cocoyam marketing and on pest and disease control informs the very crucial constraints facing cocoyam production by respondents in the study area. This is corroborated by Ifeanyi-Obi, Togun, Lamboll, Adesope \& Arokoya(2017) who found that poor access to information, poor infrastructural capacity and technology know-how where some of the major challenges faced by cocoyam farmers in the South-East region of Nigeria. Also, the finding is in agreement with Umoh (2016) who found that need for information on cocoyam processing technology, availability of marketing channel, pest and disease control, storage, improved planting materials were major constraints of cocoyam. Agricultural information needs are as important as other resources for agricultural production.

Table 5: Capacity building needs of cocoyam farmers

\begin{tabular}{|c|c|c|}
\hline Capacity Building Needs & Mean & Sd \\
\hline Effective storage of cocoyam & 3.15 & 2.77 \\
\hline Record keeping/evaluation & 2.92 & 2.58 \\
\hline Cocoyam processing technology & 3.31 & 2.95 \\
\hline Farm credit related information & 3.19 & 2.81 \\
\hline Home management practices & 2.12 & 1.99 \\
\hline Farm/health care services & 2.38 & 1.98 \\
\hline Information on effective cocoyam marketing & 2.87 & 2.59 \\
\hline Planting \& post planting operation & 1.87 & 1.62 \\
\hline Input sourcing/procurement & 2.54 & 2.28 \\
\hline Information on health benefit of cocoyam & 2.84 & 2.49 \\
\hline Pest/diseases control information & 3.17 & 2.79 \\
\hline Information on soil fertility management & 2.08 & 1.86 \\
\hline Expansion of scale of production & 1.96 & 1.77 \\
\hline Proper application of fertilizers & 1.71 & 1.38 \\
\hline Proper use of herbicide & 1.95 & 1.70 \\
\hline
\end{tabular}


Creative Commons User License: CC BY-NC-ND

Abstracted by: EBSCOhost, Electronic Journals Service (EJS),

Google Scholar, Journal Seek, Scientific Commons,

Food and Agricultural Organization (FAO), CABI and Scopus
Journal of Agricultural Extension

Vol. 25 (2) April, 2021

ISSN(e): 24086851; ISSN(Print); 1119944X

http://journal.aesonnigeria.org

http://www.ajol.info/index.php/jae

Email: editorinchief@aesonnigeria.org

Source: Field data, 2019.

\section{Constraints to Cocoyam Production}

Table 6 shows that absence of marketing information $(\bar{x}=2.69)$ was identified as a major constraint in cocoyam production and might have accounted for why the bulk of cocoyam produced were sold within the vicinity. Poor record keeping on cocoyam production was next $(\bar{x}=2.57)$. This reflects paucity of information regarding the total production of cocoyam in the study area. Labour shortage was another constraint $(\bar{x}=2.42)$. Scarcity of labour will result in high use of hired labour with its attendant high charges, which add up to cocoyam total production cost. This could be because most of traditional farm level operations are nearly zero mechanized (Dimelu, Okoye, Okoye, Agwu, Aniedu \& Akinpelu 2019). Bassey et al., (2016) remarked that with increase in population, feminization of agriculture, labour would likely be inelastic and expensive. The effect is high cost of production and consequently low returns.

High incidence of pest and disease was next with the mean $\bar{x}=2.33$. The high incidence of pest and disease will cause consideration damage and reduction in cocoyam output. This was followed by, lack of improved planting material $(\bar{x}=2.30)$, poor storage facilities $(\bar{x}=2.28)$ and inadequate processing technology $(\bar{x}=2.28)$. Poor storage facilities will lead to large post- harvest loses while lack of processing technology will also result in cocoyam being sold cheaply at farm gate rather than being processed into varieties of forces and enjoying the returns associated with value addition. This might have accounted for the high need of information on cocoyam processing technology $(\bar{x}=3.31)$ in terms of extension need of cocoyam farmers in the study area. Among other constraints that were not critical for cocoyam production in the study area were high cost of input $(\bar{x}=1.95)$, poor transportation $(\bar{x}=1.88)$, poor extension $(\bar{x}=1.85)$, land tenure $(\bar{x}=1.86)$ ignorance of the nutritive value $(\bar{x}=1.83)$, low yield $(\bar{x}=1.75)$, and low soil fertility $(\bar{x}=1.58)$ respectively.

Table 6: Constraints to cocoyam production

\begin{tabular}{lll}
\hline Constraints & Mean & Sd \\
\hline High cost of input and agro chemicals & 1.95 & 1.61 \\
Low soil fertility & 1.83 & 1.49 \\
Land tenure & 1.86 & 1.50 \\
Labour scarcity & 2.42 & 1.99 \\
Poor storage facilities & 2.28 & 1.86 \\
Lack of improved planting material & 2.30 & 1.88 \\
Pest and diseases & 2.33 & 1.90 \\
lgnorance of nutritive value of cocoyam & 1.83 & 1.49 \\
Poor extension services & 1.85 & 1.48 \\
Poor transportation system & 1.88 & 1.52 \\
Low yield of cocoyam & 1.75 & 1.45 \\
Poor record keeping on production & 2.57 & 2.12 \\
Absence of marketing information & 2.69 & 2.22
\end{tabular}


Creative Commons User License: CC BY-NC-ND

Abstracted by: EBSCOhost, Electronic Journals Service (EJS),

Google Scholar, Journal Seek, Scientific Commons,

Food and Agricultural Organization (FAO), CABI and Scopus
Journal of Agricultural Extension

Vol. 25 (2) April, 2021

ISSN(e): 24086851; ISSN(Print); 1119944X

http://journal.aesonnigeria.org

http://www.ajol.info/index.php/jae

Email: editorinchief@aesonnigeria.org

Sources: Field data, 2019.

\section{Conclusion and Recommendations}

In conclusion, majority of the farmers market their products at the farm gate. Cocoyam production in the study area has a promising economic value. But there were high-capacity building needs in Information on cocoyam processing technology, credit related information and information on effective storage of cocoyam of the farmers while the absence of marketing information was the major constraint faced by the cocoyam farmers. There is therefore the need for adequate and effective information dissemination by relevant agencies, to cocoyam farmers in the study area, to fill the identified gap, for increased production and effective marketing of what is produced.

\section{References}

Akpabio, I.A (2018). The Challenge of Agriculture in a Developing Economy, Plenary Paper Presented at the $15^{\text {th }}$ Animal Scientific Conference/AGM of the Society for Experimental Biology in Nigeria, $5^{\text {th }}-7^{\text {th }}$ May. 22pp.

Anyanwu, C. (2019), Interventions in the Agricultural Sector: How has the Nation Benefitted This Day - The Sunday Newspaper, pp31-37, February 10

Ayogu, R.N.B., Afiaenyi, I.C., Madukwe, E.U. and Udenta, E. A.(2018). Prevalence and predictors of under-nutrition among school children in a rural South-eastern Nigerian community: a cross sectional study. BMC Public Health 18, 587. https://doi.org/10.1186/s12889-018-5479-5

Bassey,E, Umoh,G.S,Ndaeyo, N.U, Nneke,N.E and Akpan, G.U (2016); Investigation in to Yaro (Colocasia esculenta) (L) Schott\} Leaf Blight Outbreak and Identification Resistant Cultivars in Akwa Ibom State Nigeria. International Journal of Current Research in Biosciences and Plant Biology. 3(5): 137- 143.

Chukwu, G.O .2016) Land Use for Cocoyam in Nigeria- Implications for Cocoyam Rebirth Global Journal of Agricultural Research Vol.3, No.2, pp.25-36

Dimelu M.U, Okoye AC, Okoye BC, Agwu AE, Aniedu OC, Akinpelu AO. (2019) Determinants of gender efficiency of small holder cocoyam farmers in Nsukka zone of Enugu State of Nigeria. Scientific Research and Essay. Mend Well Journal. 6(4):28-32.

Enibe D. O, Nwobodo, E. Cynthia M. J. Nworji and C. A. Okonkwo (2019). Economic Analysis of Cocoyam Marketing in Anambra Agricultural Zone of Anambra State, Nigeria. Asian Journal of Agricultural Extension, Economics \& Sociology 29(3): 110.

Food and Agriculture Organization (FAO, 2017), Root and Tuber Crops, Plantain and Bananas in Developing Countries: Challenges and Opportunities. Serial Paper No. 87 Pp. 11-13.

Ifeanyi-Obi, C. C., Togun, A. O., Lamboll, R., Adesope,O. M. and Arokoya, S.B. (2017). Challenges faced by cocoyam farmers in adapting to climate change in Southeast Nigeria. Climate Risk Management. 17, 155-164

Nkeme, K.K., Udo, J. and Udousung, I.J. (2017). Sustainable Environmental Management practices used by farmers in Oron Agricultural Zone of Akwa Ibom State, Nigeria. 
Creative Commons User License: CC BY-NC-ND

Abstracted by: EBSCOhost, Electronic Journals Service (EJS), Google Scholar, Journal Seek, Scientific Commons,

Food and Agricultural Organization (FAO), CABI and Scopus

http://eoi.citefactor.org/10.11226/v25i2
Journal of Agricultural Extension

Vol. 25 (2) April, 2021

ISSN(e): 24086851; ISSN(Print); 1119944X

http://journal.aesonnigeria.org

http://www.ajol.info/index.php/jae

Email: editorinchief@aesonnigeria.org

Nigeria Journal of Agriculture, Food and Environment. 13(3): 40-45.

Nwafor, Christopher U. (2018): The market channel preference among smallholder cocoyam farmers in South Africa: A food security perspective. Accessed online on http://www.preprints.org. doi:10.20944/preprints202003.0062.v1.

Okudu H. O, Okwu U. P and Umoh E J (2018) "Chemical Composition of Two Commonly Consumed Cocoyam (Colocassia esculenta) Based Dishes in Umunneochi Abia State, Nigeria". EC Nutrition 8.4 (2017): 145-151.

Omotesho K.F., Kayode A.O., Adebayo S.A., Akinrinde A.F. and Mohammed A.J. (2020).Potentials for the Commercialization of Cocoyam in Oyun Local Government Area, Kwara State, Nigeria. Journal of Tropical Agriculture, Food, Environment and Extension.19 (3)8 - 14.

Opata, Patience. Ifeyinwa (2018), Determinants of the Choice of Marketing Channel among Cocoyam Farmers in South east Nigeria. The Journal of Animal \&

Plant Sciences, 28(4): 1142-1151.

Udoh, B. T. and Akpan, U. S. (2015). Characteristics and Classification of Soils as Influenced by Parent Materials in South-Eastern Nigeria. Nigerian Journal of Agriculture, Food and Environment, 11(3):102-108

Umoh, G.S (2016): WHY DID MRS. X DIE? Reflections on Wetlands Agriculture Development in Nigeria. The $50^{\text {th }}$ Inaugural Lecture of the University of Uyo. Thursday, $27^{\text {th }}$ October. 2016 